Journal of Bangladesh Academy of Sciences, Vol. 35, No. 1, 91-97, 2011

\title{
PATHOGENIC BACTERIA, PESTICIDE RESIDUES AND METAL CONTENT IN GIANT FRESH WATER PRAWN, MACROBRACHIUM ROSENBERGII (DE MAN) SOLD IN LOCAL MARKETS
}

\author{
M. J. NAYEM, A. N. M. FAKHRUDDIN*, M. A. Z. CHOWDHURY ${ }^{1}$, M. K. ALAM ${ }^{1}$, \\ Z. FARDOUS ${ }^{1}$, H. RASHID ${ }^{1}$ AND M. A. HOSSAIN ${ }^{2}$ \\ Department of Environmental Sciences, Jahangirnagar University, Savar, Dhaka-1342, \\ Bangladesh
}

\begin{abstract}
The giant fresh water prawn, Macrobrachium rosenbergii (de Man), a leading export item of Bangladesh was studied in terms of pathogenic bacteria, pesticide residues and metal contents. In microbiological analysis, total viable bacteria, total coliform, total faecal coliform, total Salmonella and total Vibrio count were ranged from $6.8 \times 10^{4}$ to $1.6 \times 10^{6}, 1.5 \times 10^{2}$ to $1.8 \times 10^{5}, 0.0$ to $5.0 \times$ $10^{2}, 0.0$ to $1.8 \times 10^{2}$ and 0.0 to $3.6 \times 10^{2} \mathrm{cfu} / \mathrm{gm}$, respectively. Pesticide residue was analyzed by HPLC. Out of six samples studied, one was found to be contaminated with Quinalphos and another with Cypermethrin, where the concentrations were 0.03 and $0.56 \mathrm{ppm}$, respectively, below the maximum residue limit set by joint FAO/WHO expert committee. Copper $(\mathrm{Cu})$, cadmium $(\mathrm{Cd})$ and lead $(\mathrm{Pb})$ concentrations were measured by atomic absorption spectrophotometer. The range found for $\mathrm{Cu}$ and $\mathrm{Cd}$ was from 0.01 to $0.11 \mathrm{ppm}$ and 0.01 to $0.06 \mathrm{ppm}$, respectively, which is below the maximum residue limit set by joint FAO/WHO expert committee (10 ppm for $\mathrm{Cu}$ and $0.2 \mathrm{ppm}$ for Cd). Relatively high microbial load and presence of pathogens in all the tested samples, collected from local market revealed that the samples had exposure to an unhealthy environment.
\end{abstract}

Key words: Pathogenic bacteria, Macrobrachium rosenbergii, Quinalphos, Cypermethrin, Fresh water prawn

\section{INTRODUCTION}

In Bangladesh, shrimp cultivation has two wings, namely brackish-water shrimp farming and freshwater prawn farming. Among several species available in the coastal regions, Penaeus monodon Fabricius (locally known as bagda chingri) is the preferred species for brackish-water shrimp farming and attracts a very high price in international markets, followed by the giant freshwater prawn, Macrobrachium rosenbergii (de Man) (galda chingri). Freshwater prawn farming is very popular as it is cultivated in corporation with paddy and currently, one of the most important sectors of national economy of Bangladesh.

\footnotetext{
* Author for correspondence, <a.fakhruddin2@mail.dcu.ie>.

${ }^{1}$ Institute of Food \& Radiation Biology, Atomic Energy Research Establishment, Savar, Dhaka- 1344, Bangladesh.

${ }^{2}$ Microbiology and Chemical Division, Dhaka Water Supply and Sewerage Authority (DWASA), Asad Gate, Mohammadpur, Dhaka-1207, Bangladesh.
} 
Shrimp dominates the export basket of frozen foods from Bangladesh. However, Bangladesh, meanwhile, under a self imposed ban on export of shrimps (especially prawn) to the European Union (EU), a decision taken on May 2009, after 54 rejections were made from late 2008 to early 2009 due to a "Rapid Alert" notice, which circulates information on food safety problems of our export in EU.

In the early seventies, Bangladesh entered the world export market for shrimp and since then this crustacean has suddenly become a very high-priced commodity. In recent decades, due to an increased international demand, shrimp has become one of the most important export products. The shrimp sector has undergone dramatic changes in terms of area, production, and marketing. The area under shrimp production was 108,280 ha in 1990 - 91 which increased to 217, 877 ha in 2007 - 08 almost doubling (DoF 2009). On the other hand, the yield of shrimp for the same period increased from 263 to $675 \mathrm{~kg} / \mathrm{ha}$, showing a 2.57-fold increase. Two areas in the south, the Chittagong-Cox's Bazar belt and Khulna, Satkhira-Bagerhat belt, account for $95 \%$ of the total area of shrimp culture in the country. The numbers of licensed fish processing plants were 130,117. Fish processing plants approved by the EU was 67 (BFFEA 2009). The production of shrimp fry in total 400 - 550 crore and the number of shrimp hatcheries was 57 in 2007 - 08 (BFFEA 2009). The major markets for the Bangladeshi shrimp have been the USA, UK, Belgium, Germany and Japan. From 2002 - 03 to 2007 - 08 the quantity exported to the USA was on the increase. The quantity of shrimp exported to the USA was $26 \%$ of the total exported in 2002 - 03 which increased to $46 \%$ in 2007 - 08. It was only the USA where export quantity continuously increased. The quantity of shrimp exported to the UK decreased from 29 to $21 \%$ during this period. Belgium also showed a similar downward trend (BFFEA 2009).

The present study was undertaken to evaluate the food safety of the giant fresh water prawn, $M$. rosenbergii in terms of microbial pathogens, pesticide residues and heavy metal content. The objectives of the present study were to determine the prevalence of pathogenic bacteria, the residual level of pesticides and metal content in giant fresh water prawn and to compare the status with globally recommended standard.

\section{MATERIALS AND METHODS}

The samples of the giant fresh water prawn used in the experiment were aseptically collected from Savar bazaar, Dhaka and transported to the laboratory as quickly as possible for microbiological analysis.

For microbiological analysis five different types of media namely, nutrient agar medium (Difco, USA) for total viable bacterial count, MacConkey agar medium (Difco, USA) for total coliform count, $\mathrm{mFC}$ agar medium for total faecal coliform count, Thiosulfate Citrate Bile Salts Sucrose Agar medium (TCBS) for total Vibrio count, and 
S-S agar medium for total Salmonella-Shigella count were used. Standard plate count (SPC) method was used for inoculation technique, described by APHA (1998).

Pesticides from prawn samples were extracted with petroleum ether and then concentrated in a rotary vacuum. Extract was then cleaned with florisil column, eluted with diethyl ether and double distilled n-Hexane. Residual level of pesticides was analyzed with the aid of HPLC having PDA Detector (Column: C18, eluent : acetone: water $=70: 30$, flow rate: $1 \mathrm{ml} / \mathrm{min}$, injection volume: $20 \mu \mathrm{l}$, oven temperature: $30^{\circ} \mathrm{C}$ ).

In case of metal analysis, a total of 11 samples were studied according to Association of Official Agricultural Chemists (AOAC 2005). A graphite furnace atomic absorption spectrometer (GSA- EX- 71 Shimadju, Japan) was used to determine the $\mathrm{Cd}, \mathrm{Cu}$ and $\mathrm{Pb}$ concentrations of samples.

\section{RESULTS AND DISCUSSION}

In this study, a total of 12 samples of the giant fresh water prawn were analyzed for total viable bacterial count (TVBC), total coliform count (TCC), total faecal coliform count (TFCC), total Salmonella count (TSC) and total Vibrio count (TVC). The results are presented in Table 1. The total viable bacterial count varied from $6.8 \times 10^{4}$ to1.6 $\times 10^{6}$ cfu/gm. When bacterial load is $10^{6} / \mathrm{gm}$ or higher in food and food products, those foods are considered as spoiled (Conseulo et al. 1983).

Table 1. Quantitative analysis of different bacterial groups in giant fresh water prawn samples collected from local markets.

\begin{tabular}{cccccc}
\hline $\begin{array}{c}\text { Sample } \\
\text { No. }\end{array}$ & $\begin{array}{c}\text { Total viable } \\
\text { bacterial count } \\
\text { (TVBC) cfu/gm }\end{array}$ & $\begin{array}{c}\text { Total colifrm } \\
\text { count (TCC) } \\
\text { cfu/gm }\end{array}$ & $\begin{array}{c}\text { Faecal coliform } \\
\text { count (FCC) } \\
\text { cfu/gm }\end{array}$ & $\begin{array}{c}\text { Total Salmonella } \\
\text { count (TSC) } \\
\text { cfu/gm }\end{array}$ & $\begin{array}{c}\text { Total Vibrio } \\
\text { count (TVC) } \\
\text { cfu/gm }\end{array}$ \\
\hline 1 & $1.6 \times 10^{6}$ & $1.8 \times 10^{5}$ & $1.7 \times 10^{2}$ & $1.8 \times 10^{2}$ & $3.1 \times 10^{2}$ \\
2 & $6.8 \times 10^{4}$ & $7.0 \times 10^{3}$ & $5.0 \times 10^{2}$ & $4.7 \times 10$ & $3.0 \times 10^{2}$ \\
3 & $3.2 \times 10^{5}$ & $3.8 \times 10^{4}$ & $2.5 \times 10$ & $1.1 \times 10^{2}$ & $2.6 \times 10^{2}$ \\
4 & $4.5 \times 10^{5}$ & $4.7 \times 10^{4}$ & $3.1 \times 10$ & $3.1 \times 10$ & $3.6 \times 10^{2}$ \\
5 & $1.5 \times 10^{5}$ & $1.3 \times 10^{4}$ & $5.0 \times 10$ & $1.6 \times 10$ & $1.5 \times 10^{2}$ \\
6 & $4.0 \times 10^{6}$ & $1.5 \times 10^{2}$ & Nil & $2.2 \times 10^{2}$ & Nil \\
7 & $2.5 \times 10^{6}$ & $2.5 \times 10^{2}$ & Nil & Nil & Nil \\
8 & $7.0 \times 10^{5}$ & $5.8 \times 10^{4}$ & Nil & Nil & Nil \\
9 & $1.0 \times 10^{6}$ & $2.0 \times 10^{2}$ & Nil & Nil & Nil \\
10 & $4.0 \times 10^{5}$ & $3.0 \times 10^{4}$ & Nil & Nil & $2.0 \times 10^{2}$ \\
11 & $8.7 \times 10^{5}$ & $4.5 \times 10^{2}$ & Nil & Nil & $4.2 \times 10^{1}$ \\
12 & $7.0 \times 10^{6}$ & $2.0 \times 10^{4}$ & Nil & Nil & Nil \\
\hline
\end{tabular}

All of the tested samples were contaminated with coliform. The total coliform count varied from $1.5 \times 10^{2}$ to $1.8 \times 10^{5} \mathrm{cfu} / \mathrm{gm}$. Presence of coliform in food indicates sewage contamination. The total faecal coliform count varied from 0.0 to $5.0 \times 10^{2} \mathrm{cfu} / \mathrm{gm}$. 
Salmonella was found in $50 \%$ of the tested samples and the highest level recorded was $2.2 \times 10^{2} \mathrm{cfu} / \mathrm{gm}$. Out of the 12 samples, five were contaminated with Vibrio and highest level was $3.6 \times 10^{2} \mathrm{cfu} / \mathrm{gm}$. This result refers that the concerned giant fresh water prawns had an exposure to very unhygienic condition of different stages. It may start from hatcheries and other subsequent processes like farming area (gher, pond), processing station, transportation and market place. Health status of working personnels and their poor sanitation practices are also responsible. Prevalence of microbial load in shrimp was also reported (Yousuf et al. 2008).

Giant fresh water prawn was also analyzed to detect and quantify the residual levels of pesticides, namely, DDT, DDD, chloropyriphos, diazinon, malathion, carbaryl, carbofuran, cypermethrin and quinalphos and the results are presented in Table 2. Out of six samples studied, one was found contaminated with quinalphos and another one with cypermethrin.

Table 2. Pesticide residues found in the samples of the giant fresh water prawn samples collected from local market.

\begin{tabular}{cccc}
\hline Sample No. & Detected pesticide residue & Concentration $(\mathrm{ppm})$ & MRL* $(\mathrm{ppm})$ \\
\hline 01 & - & & \\
02 & - & & \\
03 & Quinalphos & 0.03 & 0.25 \\
04 & Cypermethrin & 0.56 & $0.02-2.0$ \\
05 & - & & \\
06 & - & & \\
\hline
\end{tabular}

*(Concentrations are expressed in ppm and compared with permissible limit set by FAO and WHO).

Residual concentrations of quinalphos and cypermethrin were 0.03 and $0.56 \mathrm{ppm}$, respectively, where the maximum residue limit set by joint FAO/WHO expert committee (0.25 ppm for quinalphos and $0.02-2.0 \mathrm{ppm}$ for cypermethrin). Although, the obtained results were within permitted level, but a check must be on the indiscriminate use of the pesticides. Because of lipophilic nature of different pesticides in aquatic environment, they are absorbed into fat tissues of prawn and other fishes.

Organophosphorus insecticides including quinalphos are widely used in agriculture due to their high insecticidal activity and unlike organochlorines, organophosphorus compounds are generally not biologically persistent (WHO 1989). They are toxic chemicals and irreversibly inhibit acetyl cholinesterase which is essential for the function of the central nervous system. Recent studies suggest that they might alter reproductive parameters (Battu et al. 2008). Varying degrees of testicular dysfunction have also been observed by earlier workers in experimental animals administered with different organophosphorus insecticides (Hodgson 2004). Cypermethrin is a pyrethroid insecticide. 
It works by quickly affecting the insect's central nervous system. The US EPA (1989) classified cypermethrin as a possible human carcinogen (group C) because there is limited evidence that cypermethrin is likely to cause cancer and reproductive problems or birth defects in humans. However, human being excrete cypermethrin rapidly. Both male and female rats excreted $50-65 \%$ of cypermethrin in their urine within 48 hrs of application (Hodgson 2004). In the environment, the typical half-life of cypermethrin in the soil is 30 days and soil microbes rapidly break down cypermethrin (US EPA 1989).

Quinalphos and cypermethrin are widely used in agricultural practices. Their use in paddy cultivation and vegetable farming is common. Moreover, freshwater prawn cum paddy cultivation is such a practice where strong chance of pesticide contamination to prawn exists, also for vegetable cultivation on the dikes of the gher. Besides, irrigation, surface run off, rain water percolation, water logging, flood, storms and other natural disasters are responsible for the contamination.

It is also important to trace out the metal contamination in giant fresh water prawn. Eleven samples of the prawn were analyzed to detect and quantify the concentration of metal, namely, $\mathrm{Cu}, \mathrm{Cd}$ and $\mathrm{Pb}$. The results of the metal contamination in giant fresh water prawns are shown in Table 3. Copper and cadmium were present in some tested samples. Concentration of copper in different samples ranged from 0.01 to $0.11 \mathrm{ppm}$ whereas, permissible limit is 10 ppm set by FAO and WHO (1984). The primary use of copper is in electrical equipment and as a component of many alloys it may occur together with other metals, such as Ag, Cd, Sn and Zn. Other important uses of the metal are in plumbing and heating industries and in marine environment, $\mathrm{Cu}$ is used as an anti-fouling paints. In addition, $\mathrm{Cu}$ salts may also serve as pesticides. Trace metals concentrations in shrimp from Indonesia were investigated by Soegianto and Hamami (2007) and they found the level of metals within acceptable limit.

Concentration of $\mathrm{Cd}$ in different samples ranged from 0.01 to $0.06 \mathrm{ppm}$ but permissible limit is $0.2 \mathrm{ppm}$ according to FAO and WHO (1984). It was observed that the obtained results were in permissible level. Lead was not detected in any of the studied samples. Aquatic organisms namely, crustaceans (shrimp, prawn), fish, molluscs and other invertebrates act as bio-accumulator of heavy metals (Irwandi and Farida 2009). Anthropogenic inputs are thought to be the major sources of $\mathrm{Cd}$ and $\mathrm{Cu}$ contamination.

The giant fresh water prawn is a part of aquatic environment. The abnormalities that were found in it are because of environmental pollution; and anthropogenic contribution was the most behind the pollution. Only a healthy environment can offer healthy product and services. 
Table 3. Levels of metal content found in the giant fresh water prawn samples collected from local market.

\begin{tabular}{ccccccc}
\hline $\begin{array}{c}\text { Sample } \\
\text { ID }\end{array}$ & $\begin{array}{c}\mathrm{Cu} \\
(\mathrm{ppm})\end{array}$ & $\begin{array}{c}\text { Permissible } \\
\text { limit }(\mathrm{ppm})\end{array}$ & $\begin{array}{c}\mathrm{Cd} \\
(\mathrm{ppm})\end{array}$ & $\begin{array}{c}\text { Permissible } \\
\text { limit }(\mathrm{ppm})\end{array}$ & $\begin{array}{c}\text { Pb } \\
(\mathrm{ppm})\end{array}$ & $\begin{array}{c}\text { Permissible } \\
\text { limit }(\mathrm{ppm})\end{array}$ \\
\hline 01 & 0.11 & & 0.06 & & & \\
02 & 0.10 & & 0.02 & & & \\
03 & 0.02 & & 0.01 & & & \\
04 & 0.02 & & 0.02 & & & \\
05 & 0.01 & & 0.01 & & & \\
06 & 0.02 & 10 & 0.02 & 0.2 & & \\
07 & 0.04 & & 0.03 & & & \\
08 & 0.02 & & 0.02 & & & \\
09 & 0.04 & & 0.03 & & & \\
10 & 0.03 & & 0.01 & & & \\
11 & 0.03 & & 0.02 & & & \\
\hline
\end{tabular}

$\mathrm{ND}=$ Not detected.

\section{CONCLUSIONS}

Collected prawn samples from local market showed relatively high microbial load and presence of pathogens in the tested samples which indicated that the samples had exposure to an unhealthy environment. One sample was also contaminated with quinalphos and another with cypermethrin, where the concentrations were 0.03 and 0.56 ppm respectively, below the maximum residue limit. The range found for $\mathrm{Cu}$ and $\mathrm{Cd}$ was from 0.01 to $0.11 \mathrm{ppm}$ and 0.01 to $0.06 \mathrm{ppm}$, respectively, which was below the maximum limit except sample No.1 for having $0.11 \mathrm{ppm} \mathrm{Cu}$.

\section{REFERENCES}

AOAC. 2005. Official Methods of Analysis of the Association of Analytical Chemistry. $18^{\text {th }}$ edition, Metal and other element, chapter 9, p. 19. Association of Official Analytical Chemists. Washington DC, USA.

APHA. 1998. Standard Methods for the Examination of Water and Waste water analysis. Eds. A. E. Greenberg, L. S. Clesceri and A. D. Eaton. 20 ${ }^{\text {th }}$ ed. American Public Health Association, American Water Works Association, Water Environment Federation, Washington, D.C.

Battu, R. S., B. Singh, P. K. Arora and S. K. Sahoo. 2008. Dissipation of Quinalphos in Kinnow Mandarin Fruits under Subtropical Conditions of Punjab, India. Bull Environ Contam. Toxicol. 80: $395-398$

BFFEA. 2009. Bangladesh Frozen Foods Exporters Association. Shrimp and Fish News, Bangladesh. pp. 1-2.

Consuelo, C. C., G. Guevara and Z. P. Distor. 1983. Dehydration Procedures for Machel. FAO Fisheries Rep. No.297 (Suppliment) pp. 85-92.

DOF. 2009. Jatiya Motsho Pakho. Department of Fisheries (DOF), Ministry of Fisheries and Livestock, Dhaka, Bangladesh. pp. 1-4

FAO/WHO. 1984. List of maximum levels recommended for contaminants by the Joint FAO/ WHO Codex Alimentarius Commission. Second Series. CAC/FAL, Rome 3: 1-8. 
Hodgson, E. 2004. A Textbook of Modern Toxicology. Third Edition. John Wiley \& Sons, Inc. pp. 54-64.

Irwandi, J. and O. Farida. 2009. Mineral and heavy metal contents of marine fin fish in Langkawi island, Malaysia. Int. Food Res. J. 16: 105-112.

Soegianto, A. and Hamami. 2007. Trace metal concentrations in shrimp and fish collected from Gresilk coastal water, Indonesia. Science Asia 33: 235-238.

US-EPA. 1989. United States Environmental Protection Agency. Cypermethrin Pesticide Fact Sheet 199. Washington, D.C. pp. 2-9.

WHO. 1989. Environmental Health Criteria. Cypermethrin. (Vol. 82). Geneva: United Nations Environmental Programme, the International Labour Organization, and the World Health Organization. pp. 11-17.

Yousuf, A. B., M. K. Ahmed, S. Yeasmin, N. Ahsan, M. M. Rahman and M. M. Islam. 2008. Prevalence of microbial load in shrimp, Penaeus monodon and prawn, Macrobrachium rosenbergii from Bangladesh. World J. Agri. Sci. 4: 852-855.

(Received revised manuscript on 8 May, 2011) 